(C) 2019Palaguta. This article is distributed under the terms of CC Attribution-Share Alike 4.0 Internationalas described at https://creativecommons.org/ licenses/by-sa/4.0.

UDC: 377.8

DOI:10.31499/

\title{
SUPPORT TO TEACHERS' PROFESSIONAL DEVELOPMENT IN UKRAINE AND ENGLAND: EVIDENCE FROM TALIS SURVEY
}

\author{
Ilona Palaguta \\ Lecturer at Foreign Languages Department, \\ Pavlo Tychyna Uman State Pedagogical University, Uman, Ukraine \\ ORCID: 0000-0001-6001-7929,e-mail: ilonapalaguta@i.ua
}

In the article the basic problems of the pedagogical support of teacher's professional development in Ukraine and England are analyzed.

In the process of future teacher's professional development, qualified teachers should support young teachers, because they do not have an experience, the knowledge of human nature, skills of self-organization and self-regulation.

It is very important to know the teachers' needs in professional development for helping them to solve difficulties, which will appear in their professional life, to expand and extend their knowledge and skills, obtained during their training at the university and provide a basis for constant professional development.

A comparative analysis of the needs of Ukrainian and English teachers in their professional development is described. In our view, a comparative analysis of the needs of Ukrainian and English teachers in their professional development might be important since in Ukraine the issue of teachers' professional development has been investigated, but there is still much to be considered. Thus, it will be useful to address the foreign experience in such a question, especially to the experience of Great Britain where teachers continuous professional development is of top priority.

Learning International Survey (TALIS) conducted in Ukraine and England is characterized. In Ukraine, the Ukrainian Educational Research Association conducted the survey based on TALIS methodology in 2017. The aim of it is to study the educational environment and conditions of teachers' work: identification of teachers' training and professional development, studying the nature of school's culture, analysis of values and professional ideas of teachers.

Three main TALIS questionnaires items are enumerated. The main focus of attention to be taken into account the teachers' awareness of what mentoring is and what forms and functions are meant by it is raised.

The new Conception of Pedagogical Education Development in Ukraine takes into account both pre-service and in-service teachers' education [5]. It is presented as an internship period. According to the above-mentioned document, novice teachers work under the supervision of experienced teachers.

Key words: professional development, pedagogical support, future teacher, professional activity, TALIS methodology.

У статті проаналізовано основні проблеми педагогічної підтримки майбутніх учителів в Украйні та Англї. Пояснюються труднощі входження 
майбутнъого вчителя у професійну діяъністъ. Описано порівняльий аналіз потреб украйнсъких та англійських вчителів щодо їхнього професійного зростання $b$ Украйні та Англії. Представлено порівняльий аналіз та результати Всеукрайнського моніторингового опитуВання Викладання та навчання серед директорів і вчителів загальноосвітніх навчальних закладів (за методологією TALIS) $b$ Украйні та Англії. Означено корисність досвіду щзодо розвитку педагогічної підтримки у зарубіжних крайнах, зокрема $В$ Англії, а також Використання досвіду иієї крайни у педагогічній підтримиі професійного розвитку майбутніх учителів в Украйні.

Ключові слова: професійний розъиток, педагогічна підтримка, майбутній учитель, професійна діялність, методологія TALIS.

Introduction. Modern European educational society shows a great interest in the policy of supporting future teacher's professional development. The period of initial teacher's professional socialization is recognized as the most stressful because it is associated with the transition to a new system of social relations.

In the process of future teacher's professional development, qualified teachers should support young teachers, because they do not have an experience, the knowledge of human nature, skills of self- organization and self-regulation.

It is very important to know the teachers' needs in professional development for helping them to solve difficulties, which will appear in their professional life, to expand and extend their knowledge and skills, obtained during their training at the university and provide a basis for constant professional development.

In our view, a comparative analysis of the needs of Ukrainian and English teachers in their professional development might be important since in Ukraine the issue of teachers' professional development has been investigated, but there is still much to be considered. Thus, it will be useful to address the foreign experience in such a question, especially to the experience of Great Britain where teachers continuous professional development is of top priority.

Our conclusions according to the needs of Ukrainian and English teachers in their professional development help to show some key points to consider and to adapt the experience of English teachers' professional development to Ukrainian context.

Methods. The comparative analysis is based on the evidence received from the Teaching and Learning International Survey (TALIS) conducted in Ukraine and England.

In England, the Organisation for Economic Co-operation and Development has conducted TALIS in 2013 and 2018; nevertheless, we rely on TALIS 2013 data as they have already been open for researchers. School principals and teachers provided information about issues such as the professional development they have received; their teaching beliefs and practices; the review of teachers' work and the feedback and recognition they receive about their work; and various other workplace issues such as school leadership and school climate [2].

In Ukraine, the Ukrainian Educational Research Association conducted the survey based on TALIS methodology in 2017. The aim of it is to study the educational environment and conditions of teachers' work: identification of teachers' training and professional development, studying the nature of school's culture, analysis of values and professional ideas of teachers, etc [4].

Ukrainian and English teachers received questionnaires with similar ques-tions. We realize that these two surveys were conducted in different years, but the problem of teachers' professional development is still in the focus of attention and the results can serve for defining the tendencies for teachers' professional develop-ment in England and Ukraine, thus providing some information to take into account in Ukrainian teachers' professional 
development programmes.

Results. The comparative analysis is based on the information received from answering the following TALIS questionnaires items:

1. Do new teachers at this school have access to an induction programme?

2. What structures and activities are included in this induction programme?

3. Do teachers at your school have access to a mentoring system?

The question about induction programmes concerned schools where they were provided and teachers who participated in them. The table below demonstrates the percentage of Ukrainian and English teachers who work in schools with induction programmes as well as the percentage of teachers who had an induction in their first year (see Table 1).

As we see from Table 1, in England 99\% of teachers work in schools where the head reports that there is an induction programme, either for all new teachers to the school or just for teachers who are new to teaching. This situation reflects the legal requirement that 'statutory induction' for teachers takes place in Local Authority maintained schools [4].

As for Ukraine, $93 \%$ of teachers work in schools where the head reports that there is an induction programme.

According to the data Table 1, in Ukraine and England, a great number of teachers have access to induction programmes (93\% and $9 \%$ respectively).

It should be mentioned that there might be some difference in Ukrainian teachers' understanding of what mentoring and induction are. As the UERA members who conducted the surveyed mentioned, there were many questions from the surveyed about the mentor's functions and they connected it to the teacher super-visor who is traditionally assigned for new teachers at school (interview with Ukrainian researchers who conducted Teaching and Learning International Survey not published).

No official documents are regulating the supervisor's work in Ukraine. Neither their work is credited or paid for. It is more a voluntary additional function performed by more experienced teachers. As for induction programmes Ukrainian teachers are introduced to them through primary socialization programmes that is a set of activities targeted to notice a teacher to induct them to their profession, presenting them their principal functions, school traditions and routine.

Also, we can mention that in England $76 \%$ of teachers had an induction in the first year, but in Ukraine $66,7 \%$ had it. To compare Ukrainian and British results, we can say, that it is only $10 \%$ of divergences in this issue which demonstrates that notice teachers' professional socialization is in the focus of attention in both countries.

\section{Percentage of teachers in Ukrainian and British schools with induction programmes}

Table 1

\begin{tabular}{l|c|c} 
Percentage of teachers & England & Ukraine \\
\hline In schools with induction programmes & $99^{*}$ & $93^{* *}$ \\
\hline who had an induction in the first year & $76^{*}$ & $66,7^{* *}$ \\
\hline & & \\
* data is taken from TALIS 2013 &
\end{tabular}

The second question concerned activities which were included in the induction programme. It sought information about particular activities included in the induction programmes, namely:

- courses/workshops; 
- mentoring and/or peer observation and coaching;

- conferences/seminars;

- individual or collaborative research;

- observation visits to other schools;

- qualification programme;

- observation visits to other organizations.

In the TALIS questionnaire, the list included both formal and informal activities, and the conducted research provided us with the information that can be used in comparing Ukrainian and British situation in such an issue.

The survey results demonstrate that the professional development activities that are the most popular with Ukrainian teachers are education conferences or seminars (where teachers and/or researchers present their research results and discuss educational issues). $86,4 \%$ of Ukrainian teachers reported their participation in educational conferences and seminars. In Ukraine, those surveyed might mean any gathering where educational issues are discussed which do not imply either prior preparation or presenting the research carried out by the teachers [3], which is quite different from England.

The received data show that $65,4 \%$ of Ukrainian teachers participated in some courses or workshops (e.g., on the subject matter or methods and/or other edu-cation-related topics) which in the average took them 10,6 days.

As reported, mentoring and/or peer observation and coaching, as part of a formal school arrangement are practised by $67,9 \%$ of Ukrainian teachers. As men-tioned above, less than a quarter of Ukrainian teachers work as mentors which may mean that such a high percentage is demonstrated due to active peer observation at Ukrainian schools. It is proved by the fact that $69,6 \%$ of Ukrainian teachers report participating in observation visits to other schools.

In this aspect, the data received from Ukrainian teachers about their participation individual or collaborative research raise a considerable interest.

In Simon Borg's «Conditions for Teacher Research» (Borg, 2006) one of the key characteristics of teachers' research is making its results public. Owing to the fact that Ukrainian teachers rarely have results of their researches published. We have a ques-tion concerning a high percentage of teachers engaged in individual and colla-borative research in Ukraine $(55,9 \%)$ and believe that this requires further research.

Another issue that requires an additional comment is the high percentage of Ukrainian teachers who mentioned that they participate in qualification program-mes. The fact is that higher education in Ukraine is becoming more egalitarian. That means that the entrance requirements are getting lower and tuition fees are quite affordable, thus the considerable number of teachers get their second University education.

Not many Ukrainian teachers participate in observation visits to other premises $(20,2 \%)$ or in in-service training courses organized by business, public orga-nizations, or non-governmental organizations.

As for England, the survey results demonstrate that the professional develop-ment activities that are the most popular with British teachers are courses and workshops (where teachers and/or researchers present their research results and discuss educational issues) (75\%).

Broadly speaking, the activities most commonly reported in England are: courses and workshops, mentoring, peer observation and coaching, conferences and seminars, etc. It should be noted that participation in courses and seminars, men-toring, observation and coaching (57\%) is more frequently reported in England and going to observations visits to other organization reported less frequently $(7 \%)$ [4]. 
$29 \%$ of British teachers reported their participation in educational conferences and seminars, $27 \%$ in Individual or collaborative research.

Also, teachers in England take part in observation visits to other schools, it is only $20 \%$ and $10 \%$ take some qualification programmes.

According to the Table 2, we can mention that in Ukraine and England there are similar professional development activities with conferences and seminars as the most frequent ones in Ukraine and courses and workshops as the most practised in England. A great number of teachers take part in them.

Table 2

Percentage of Ukrainian and British teachers reported participation in different types of CDP

\begin{tabular}{l|c|c} 
Types of CDP & England & Ukraine \\
\hline Courses/workshops & $75^{*}$ & $65,4^{* *}$ \\
\hline Mentoring and/or peer observation and coaching & $57^{*}$ & $67,9^{* *}$ \\
\hline Conferences/seminars & $29^{*}$ & $86,4^{* *}$ \\
\hline Individual or collaborative research & $27^{*}$ & $55,9^{* *}$ \\
& & Continuation table 2
\end{tabular}

\begin{tabular}{l|c|c} 
Observation visits to other schools & $20^{*}$ & $69,6^{* *}$ \\
\hline Qualification programme & $10^{*}$ & $43,8^{* *}$ \\
\hline Observation visits to other organizations & $7^{*}$ & $20,2^{* *}$
\end{tabular}

* data is taken from TALIS 2013

** data is taken from the UERA survey 2017

Thus, a few issues drew our attention, these are: a high percentage of Ukrainian teachers participating in conferences and seminars (93\%) which is much higher than that in England (29\%), a high percentage of Ukrainian teachers who reported mentoring and/or peer observation and coaching as widely practiced forms of professional development.

There is a certain discrepancy in the data if we compare the results with those received in teachers answering the question about their being mentored and acting as mentors.

The table below demonstrates the percentage of Ukrainian and English teachers in schools with mentoring systems, who have mentors, and who act as mentors (see table 3 ).

In England, 19\% of teachers confirmed that they have been mentored and $31 \%$ acted as mentors.

In Ukraine $15,9 \%$ of teachers said that they have been mentored, $25,8 \%$ acted as mentors, which casts some doubt on Ukrainian teachers being consistent in providing information. Anyway, if we sum up the percentage of teachers presenting both categories (being mentored and mentoring) we will get $44,4 \%$ which is considerably less than $67,9 \%$ reported by teachers about participating in mentoring and coaching as part of their continuous professional development. 
To compare Ukrainian and British results, we can say, that Ukrainian and British teachers have no considerable problems with access to a mentoring system, both have an opportunity to improve their professional activity.

Table 3

\section{Percentage of teachers in schools with mentoring systems, who have mentors, and who act as mentors}

\begin{tabular}{l|c|c} 
Percentage of teachers & England & Ukraine \\
\hline being mentored & $19^{*}$ & $15,9^{* *}$ \\
\hline acting as mentors & $31^{*}$ & $28,5^{* *}$
\end{tabular}

* data is taken from TALIS 2013

** data is taken from the UERA survey 2017

Discussion. After the TALIS comparative analyses of some aspects of teachers' professional development in Ukraine and England, we have noticed that:

- the main activities in teachers' professional development in Ukraine and England go under some names but might be understood differently by teachers;

- since Ukraine has been rather passive as to participating in international surveys, Ukrainian teachers do not demonstrate a high culture of participating in the surveys which can be seen from considerable differences in their answers.

Thus, the main focus of attention to be taken into account is raising the teachers' awareness of what mentoring is and what forms and functions are meant by it.

In England, teachers who are authorized to work as mentors undergo special training. Their work has a legislative background and is regulated by the National Standards for school-based initial teacher training mentors [2].

Conclusions. For the efficient supporting teachers' professional development in Ukraine, it is necessary that mentoring should gain the appropriate background in the form of national standards and mentor's practical document kit. The next thing to do is to develop the practice of teacher conducting classroom research with further sharing the results with educational researchers and practitioners at conferences and seminars. And finally, the practice of evidence-based on educational policies should be broadened as developing teachers' survey culture might bring teachers' continuous professional development up to standard.

\section{References:}

1. Borg S. 2006. Conditions for Teacher Research, p. 22-27.

2. Carter A. 2016. National Standards for school-based initial teacher training mentors, $18 p$.

3. Madalinska-Michalak J. 2018. Teacher Leadership, 420 p.

4. $\quad$ Micklewright J., Jerrim J., Vignoles A., Jenkins A., Allen R., Ilie S., Bellarbre E., Barrera F. E Hein C. 2014.Teachers in England's secondary schools :evidence from TALIS 2013: Research report, 206 p.

5. Shudlo S., Zabolotna O., Lisova T. 2018. Ukrainski vchyteli ta navchalne seredovyshche. Za rezultatamy Vseukrainskoho monitorynhovoho opytuvannia vykladannia ta navchannia sered dyrektoriv $i$ vchyteliv zahalnoosvitnikh navchalnykh zakladiv (za metodolohiieiu TALIS), 300 p. 
Accepted: June, 2 